\title{
Facies, cycles, and controls on the evolution of a keep-up carbonate platform (Kimmeridgian, Swiss Jura)
}

\author{
CLAUDE COLOMBIÉ* and ANDRE STRASSER $\dagger$ \\ *UMR 5125, UFR Sciences de la Terre, Université Claude Bernard Lyon 1, Domaine Scientifique \\ de la Doua, Bât. GÉODE, 2 rue Raphaël Dubois, 69622 Villeurbanne Cedex, France (E-mail: \\ claude.colombie@univ-lyon1.fr) \\ $\dagger$ Department of Geosciences, Geology-Palaeontology, University of Fribourg, 1700 Fribourg, Switzerland
}

\begin{abstract}
During the Late Jurassic, accelerated ocean-floor spreading and associated sealevel rise were responsible for a worldwide transgression, which reached its maximum in the Late Kimmeridgian. In many Western European basins, this major sea-level rise led to the formation of marly and condensed sections. In the Swiss Jura, however, a shallow carbonate platform kept growing and only subtle changes in the stratigraphic record suggest an increasingly open-marine influence. Field observations and thin-section analyses reveal that the central Swiss Jura was at that time occupied by tidal flats and by more or less open marine lagoons where shoals and bioherms developed. The evolution through time of sedimentary facies and bed thicknesses permits the definition of small-, medium-, and large-scale depositional sequences. The diagnostic features of these sequences are independent of scale and seem largely controlled by the Kimmeridgian second-order transgression. A high-resolution sequencestratigraphic correlation with biostratigraphically well-dated hemipelagic and pelagic sections in the Vocontian Basin in France reveals that: (i) The most important increase in accommodation recorded in the Kimmeridgian of the central Swiss Jura occurs in the Eudoxus ammonite zone (Late Kimmeridgian) and corresponds to the second-order maximum flooding recognized in many sedimentary basins. (ii) The small- and medium-scale sequences have time durations corresponding to the first and second orbital eccentricity cycle (i.e. 100 and $400 \mathrm{ka}$, respectively), suggesting that sedimentation on the platform and in the basin was at least partly controlled by cyclic environmental changes induced by insolation variations in the Milankovitch frequency band. The comparison of the high-resolution temporal framework defined in the Swiss Jura and Vocontian Basin with the sequencestratigraphic interpretation realized in other Western European basins shows that the large-scale sequence boundaries defined in the Kimmeridgian of the Swiss Jura appear in comparable biostratigraphic positions in most Western European basins. Discrepancies that occur are probably because of local or regional tectonics.
\end{abstract}

Keywords Cyclostratigraphy, high-resolution sequence stratigraphy, keep-up carbonate platform, Kimmeridgian, stratigraphic correlation, Swiss Jura.

\section{INTRODUCTION}

Variations in subsidence and eustatic sea level are responsible for the formation of transgressiveregressive sedimentary sequences. Relative sea- level rise commonly leads to a transgression and deepening facies trend. However, high sedimentation rate may keep pace with or exceed the increase of accommodation, and result in aggradational or progradational deposits respectively 
(Kendall \& Schlager, 1981; Jones \& Desrochers, 1992; Posamentier et al., 1992; Handford \& Loucks, 1994; Hunt \& Tucker, 1995). In this paper, a case study from the Kimmeridgian (Late Jurassic) in the Swiss Jura Mountains is presented, where a shallow-water carbonate platform kept growing with rising sea level over several million years.

During the Kimmeridgian, the break-up of Pangea was in an active phase (Ziegler, 1988; Dercourt et al., 1993; Thierry, 2000). Accelerated ocean-floor spreading, associated sea-level rise, and high atmospheric carbon dioxide levels were probably responsible for the worldwide transgression (Hallam, 1985; Weissert \& Mohr, 1996), which started in the Late Oxfordian and ended in the Late Kimmeridgian (Hardenbol et al., 1998). The related major transgressive trend can be traced in successions from southern England to Greenland (Wignall, 1994; Taylor et al., 2001), and is recognized in many other Western European basins (e.g. Marques \& Olóriz, 1989; Proust et al., 1995). In Portugal and northern France, this major sea-level rise resulted in the formation of marly and condensed sections. In the Swiss Jura, however, only subtle changes in the stratigraphic record suggest an increasingly open-marine influence.

In this study, a detailed sedimentological, sequence-stratigraphic and cyclostratigraphic analysis was carried out on three sections in the Swiss Jura. The sedimentary sequences are placed into a sequence-stratigraphic framework and the controls on their formation are discussed. A comparison is drawn subsequently between the high-resolution stratigraphic framework defined in the Kimmeridgian of the Swiss Jura with the sequence-stratigraphic interpretation developed for successions from other Western European basins (north-eastern Spain, western and central Portugal, northern France, and southern England).

\section{PALAEOGEOGRAPHIC AND STRATIGRAPHIC SETTING}

The Jura platform was located between the Paris Basin to the NW and the Ligurian segment of the Mesozoic Tethys to the SE (Fig. 1). This SW-NE trending shallow carbonate platform was bounded in the south and SE by more or less continuous bioclastic and oolitic barriers, and by coral reefs (Enay et al., 1988). Small quantities of terrigenous material (quartz, clays, plant debris) occur episodically in the Kimmeridgian of the Swiss Jura, derived from the emerged massifs located to the west, north and east (Bolliger \& Burri, 1970; Gygi \& Persoz, 1986).

In the central Swiss Jura, the Kimmeridgian corresponds to the Reuchenette Formation (Thalmann, 1966; Gygi, 1995; Fig. 2). It is a thick succession ( $140 \mathrm{~m}$ on the average) of shallowwater limestones. Precise biostratigraphic dating is lacking, but the lower and upper boundaries of this formation correspond to lithological marker beds that are thought to be more or less isochronous (Gygi, 2000). The lower boundary of the Reuchenette Formation coincides with the top of the white oolitic limestones of the Late Oxfordian Verena Member. It is characterized by an abrupt texture change (from packstone/grainstone to mudstone), the development of restricted ecological conditions, and an increase of quartz content (Colombié, 2002). The upper boundary of the formation is indicated by the 'Banc à Nérinées'

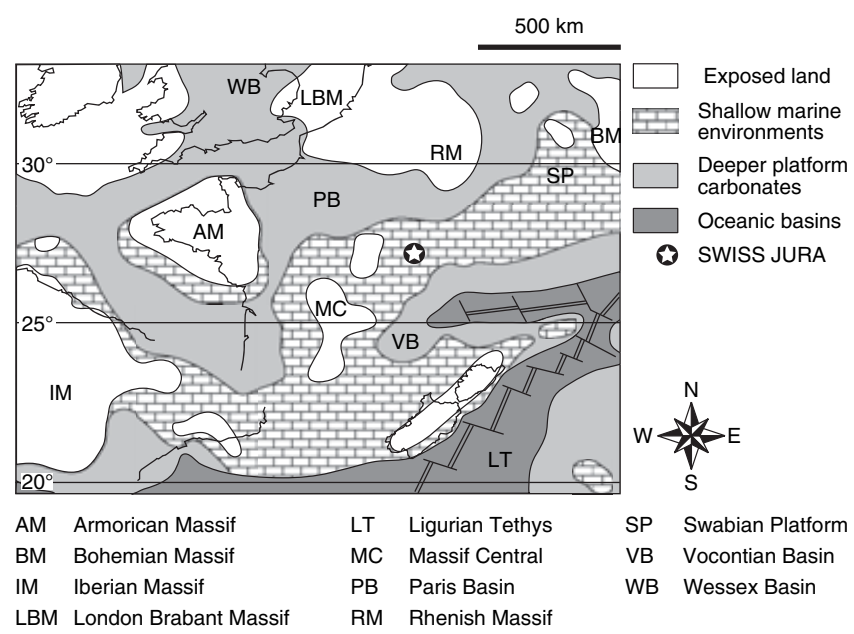

Fig. 1. Palaeogeographical map for the Early Kimmeridgian (146$144 \mathrm{Ma})$ modified from Thierry et al. (2000). 


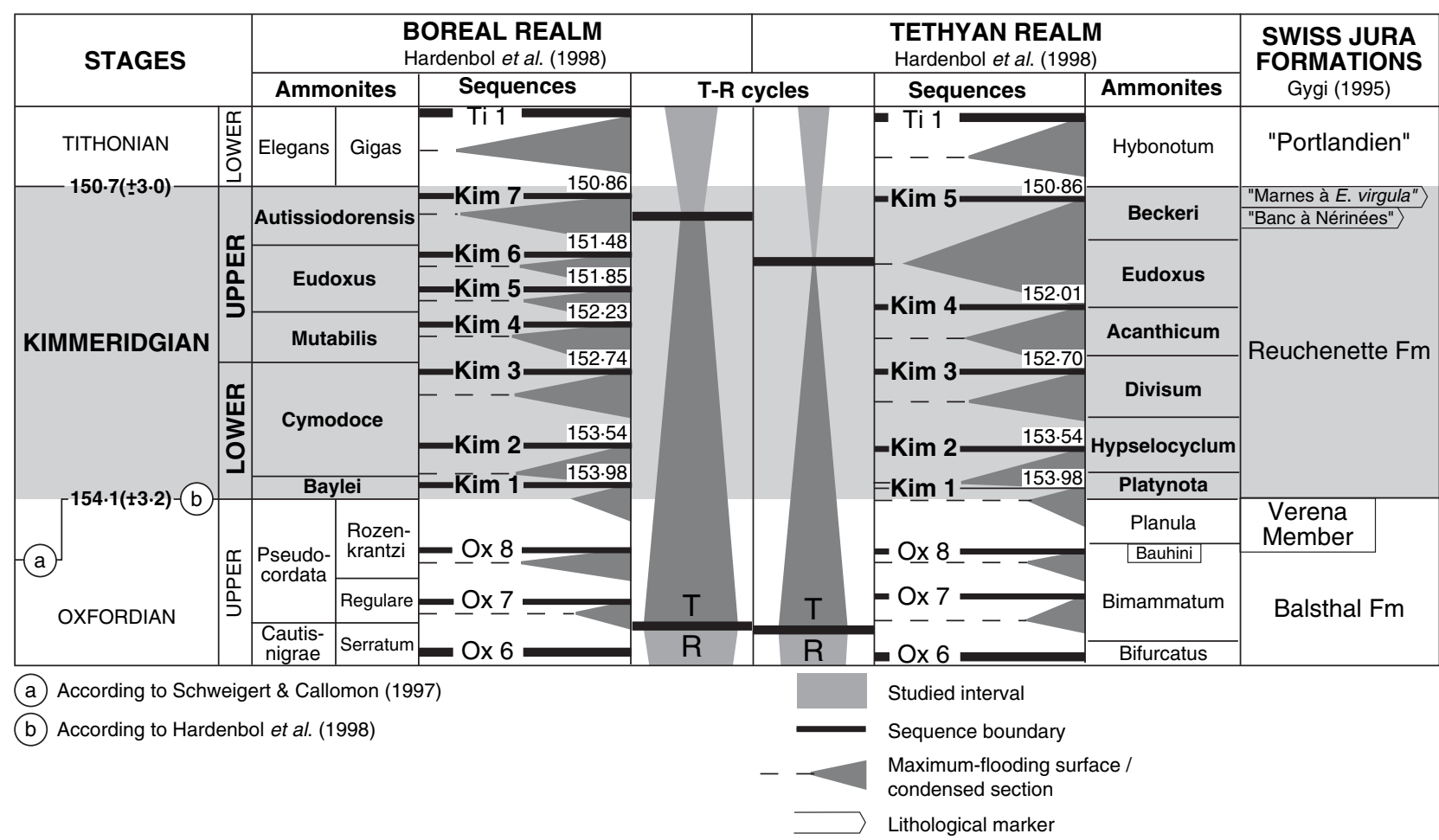

Fig. 2. Stratigraphic chart of the studied interval and associated formations in the Swiss Jura. Ages of stage and sequence boundaries in Ma.

(Dauwalder \& Remane, 1979), a heavily bored hardground (Meyer, 1994), the 'Marnes à Exogyra virgula' (Aubert, 1932, 1950), and/or the appearance of the 'Calcaires en Plaquettes', thinly bedded peritidal limestones and dolostones attributed to the base of the 'Portlandien' (i.e. Tithonian).

In the Tethyan realm, the Kimmeridgian comprises the interval between the Platynota and the Beckeri ammonite zones (Fig. 2). It would thus correspond to the Baylei to Autissiodorensis zones of the northern European region (Hardenbol et al., 1998). However, based on amoeboceratid ammonites, Schweigert \& Callomon (1997) correlate the base of the boreal Kimmeridgian with the Bauhini horizon at the top of the Tethyan Bimmamatum zone. The two versions of correlation are included in Fig. 2. Moreover, although the ammonites of the Swiss Jura show a Tethyan affinity in the Early Kimmeridgian, they suggest boreal influences in the Late Kimmeridgian (Gygi, 1995). The boreal zonation is therefore used in the upper part of the studied sections.

According to regional platform-to-basin correlations based on ammonites as well as on quartz and clay-mineral contents (Gygi \& Persoz, 1986), the top of the Verena Member lies at the top of the Planula ammonite zone. The upper boundary of the Reuchenette Formation is located in the Autissiodorensis zone, corresponding to the Tethyan Beckeri zone (Meyer \& Pittman, 1994; Gygi, 1995). Gravesia polypleura HAHN was found $35 \mathrm{~m}$ above the 'Banc à Nérinées' (Thalmann, 1966) and indicates that the 'Calcaires en Plaquettes' (Portlandien) has to be placed in the Gigas zone (equivalent to the lower part of the Tethyan Hybonotum zone). This is confirmed by the occurrence in the lowermost 'Portlandien' of the ostracod Macrodentina (M.) klingeri MALZ, which is characteristic of the Autissiodorensis and Gigas zones (Häfeli, 1966; Meyer, 1993).

The studied interval includes five third-order sequence boundaries (Kim 1 to Kim 5; Hardenbol et al., 1998), which are calibrated to the absolute time scale of Gradstein et al. (1994). However, the ages attributed to the stage boundaries have large margins of error (Fig. 2), and the apparently precise dating of the sequence boundaries is an artefact of interpolation.

\section{METHODS}

A detailed sedimentological, sequence and cyclostratigraphic analysis has been performed on three sections located to the north of Biel in the 


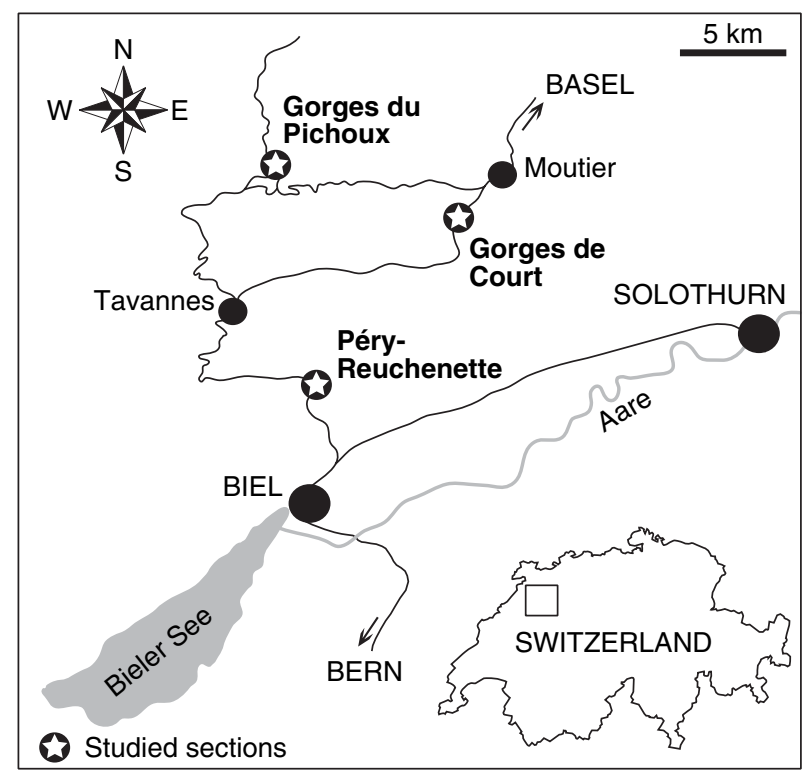

Fig. 3. Geographical location of the studied sections in the central Swiss Jura.

central Swiss Jura (Fig. 3). The Gorges du Pichoux section measures $180 \mathrm{~m}$, the Gorges de Court section $140 \mathrm{~m}$, and the Péry-Reuchenette section $173 \mathrm{~m}$. The horizontal distances between the sections are about $10 \mathrm{~km}$. The outcrops are almost continuous and relatively undeformed. Field observations include weathering profile, lithology, and sedimentary structures, whereas analysis of 650 slabs and 530 thin sections allowed for the definition of microfacies (Flügel, 1982). From these data, the depositional environments are interpreted.

According to the sedimentological interpretation and the stacking pattern of beds, depositional sequences are defined independently in each section and then correlated to filter out autocyclically created beds (Strasser, 1991; see also methodology described in Strasser et al., 1999). Several orders of depositional sequences are identified. They are hierarchically stacked, suggesting an orbital control on sedimentation. In order to confirm this interpretation, the platform sections, where a precise biostratigraphic and chronostratigraphic framework is lacking, are correlated with the time-equivalent and biostratigraphically well-dated succession in the Vocontian Basin in France (Atrops, 1982). The durations of the depositional sequences (as deduced from their number between dated sequence boundaries or dated limits of ammonite zones) confirm that they formed in tune with Milankovitch orbital parameters. The resulting high-resolution temporal framework is then compared with the chronostratigraphic chart of Hardenbol et al. (1998) and with the sequence boundaries defined in other Western European basins.

\section{FACIES ANALYSIS AND ENVIRONMENTAL INTERPRETATION}

Sedimentary facies reflect the physical and chemical conditions of depositional environments. In carbonate systems, facies analysis also permits interpretation of the ecology of the carbonateproducing organisms, which are influenced by temperature, salinity, energy and depth of water, as well as by siliciclastic input, nutrient supply, oxygen content and light (e.g. Hallock \& Schlager, 1986; Schlager, 1993; Homewood, 1996; James, 1997).

In the studied sections, 19 facies have been identified based on texture, main constituents, fabrics, early diagenetic features, as well as fossil content (Fig. 4). These are interpreted to represent 12 sub-environments that group into four environments. For example, the tidal flat environment contains marsh, pond, intertidal flat, and tidal channel sub-environments, each of which has characteristic facies. In accordance with studies on modern and ancient peritidal carbonate systems (Laporte, 1967; Hardie \& Ginsburg, 1977; Shinn, 1983; Strasser \& Davaud, 1983; Pratt \& James, 1992), the sedimentological interpretation leads to a facies model reflecting the spatial distribution of the different environments and sub-environments defined in the Kimmeridgian of the central Swiss Jura (Fig. 5).

\section{Tidal flat environment}

\section{Marsh sub-environment}

Bioturbated mudstones with desiccation features (circum-granular cracks, desiccation cracks, tepees, and/or fenestrae) indicate low-energy depositional environments between the upper intertidal and supratidal zones (Laporte, 1967; Shinn et al., 1969; Shinn, 1983; Pratt \& James, 1992). Peloids and bioclasts constitute up to $50 \%$ of coarse sediment layers that are several millimetres to centimetres thick, graded or ungraded, with or without planar lamination. They result from spring- or storm-tide deposition in the upper intertidal and supratidal zones (Shinn, 1983). Thin layers of dolomite or peloids alternating with micrite are considered to be stromatolites (Dupraz, 1999). They occur on tidal flats from 


\begin{tabular}{|c|c|c|c|}
\hline Texture & Main constituents & Fabrics and diagenetic features & Fossil content \\
\hline \multirow{2}{*}{\multicolumn{4}{|c|}{$\begin{array}{l}\text { TIDAL FLAT ENVIRONMENT } \\
\text { Marsh subenvironment (supratidal to upper intertidal) }\end{array}$}} \\
\hline & & & \\
\hline Mudstone & & $\begin{array}{l}\text { Circum-granular cracks, desiccation cracks, } \\
\text { tepees, fenestrae, coarse sediment layers } \\
\text { (peloids, bioclasts), alternating dolomite-rich and } \\
\text { micrite laminae, alternating peloid-rich and } \\
\text { micrite laminae, bioturbation }\end{array}$ & $\begin{array}{l}\text { Lack of fossils or low } \\
\text { fossil diversity (ostracods, } \\
\text { pelecypods, miliolids) }\end{array}$ \\
\hline \multicolumn{4}{|c|}{ Pond subenvironment (supratidal to intertidal) } \\
\hline Mudstone & $\begin{array}{l}\text { Charophytes } \\
\text { (gyrogonites and stems) }\end{array}$ & Bioturbation & $\begin{array}{l}\text { Low fossil diversity } \\
\text { (ostracods, pelecypods, } \\
\text { miliolids) }\end{array}$ \\
\hline \multicolumn{4}{|c|}{ Intertidal flat subenvironment (lower intertidal) } \\
\hline Mudstone & & $\begin{array}{l}\text { Alternating micrite and dolomite-rich laminae, } \\
\text { alternating micrite and peloid-rich laminae, } \\
\text { bioturbation }\end{array}$ & $\begin{array}{l}\text { Low fossil diversity (ostracods, } \\
\text { pelecypods, miliolids) }\end{array}$ \\
\hline \multicolumn{4}{|c|}{ Tidal channel subenvironment (upper subtidal) } \\
\hline \begin{tabular}{|l|} 
Grainstone \\
and \\
Wackestone/ \\
packstone
\end{tabular} & Peloids & $\begin{array}{l}\text { Alternating planar oblique bedding and } \\
\text { strong bioturbation }\end{array}$ & $\begin{array}{l}\text { Moderate fossil diversity (ostracods, } \\
\text { pelecypods, gastropods, miliolids, } \\
\text { other benthic foraminifera, } \\
\text { dasycladaceans, sponge spicules) }\end{array}$ \\
\hline \multicolumn{4}{|c|}{ BEACH ENVIRONMENT } \\
\hline $\begin{array}{l}\text { Packstone/ } \\
\text { grainstone }\end{array}$ & Peloids, oncoids & Planar bedding, keystone vugs & $\begin{array}{l}\text { Low fossil diversity (ostracods, } \\
\text { pelecypods, miliolids) }\end{array}$ \\
\hline \multicolumn{4}{|c|}{$\begin{array}{l}\text { LAGOON ENVIRONMENT } \\
\text { Restricted lagoon subenvironm }\end{array}$} \\
\hline \multirow{2}{*}{\begin{tabular}{l|l} 
Mudstone \\
Grainstone
\end{tabular}} & Dolomite, ostracods & Gypsum nseudomornhs bioturbation & Low fossil diversity (ostracods, \\
\hline & Peloids & 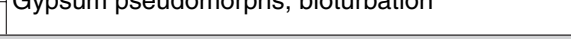 & pelecypods, miliolids), calcispheres \\
\hline \multicolumn{4}{|c|}{ Semi-restricted lagoon subenvironment } \\
\hline \multicolumn{2}{|c|}{\begin{tabular}{l|l} 
Mudstone & \\
\end{tabular}} & \multirow{4}{*}{ Bioturbation } & \multirow{4}{*}{$\begin{array}{l}\text { Moderate fossil diversity (ostracods, } \\
\text { pelecypods, gastropods, miliolids, } \\
\text { other benthic foraminifera, } \\
\text { dasycladaceans, sponge spicules), } \\
\text { calcispheres, Bacinella, } \\
\text { Cayeuxia, Marinella, } \\
\text { Thaumatoporella, Cladocoropsis }\end{array}$} \\
\hline Wackestone & $\begin{array}{l}\text { Ostracods, pelecypods, sponge } \\
\text { spicules, dasycladaceans, } \\
\text { oncoids }\end{array}$ & & \\
\hline $\begin{array}{l}\text { Wackestoned } \\
\text { packstone }\end{array}$ & $\begin{array}{l}\text { Ostracods, pelecypods, sponge } \\
\text { spicules, Marinella, peloids, } \\
\text { oncoids, ooids (type } 1,2 \text { or } 4 \text { ) }\end{array}$ & & \\
\hline Grainstone & Peloids & & \\
\hline \multicolumn{4}{|c|}{ Sheltered lagoon subenvironment } \\
\hline Wackestone & $\begin{array}{l}\text { Ostracods, pelecypods, } \\
\text { sponge spicules, peloids, oncoids }\end{array}$ & \multirow{2}{*}{ Bioturbation } & \multirow{2}{*}{$\begin{array}{l}\text { High fossil diversity (ostracods, } \\
\text { pelecypods, gastropods, } \\
\text { miliolids, other benthic foraminifera, } \\
\text { dasycladaceans, sponge spicules, } \\
\text { abundant echinoderms), } \\
\text { Bacinella, Cayeuxia, Marinella, } \\
\text { Cladocoropsis }\end{array}$} \\
\hline $\begin{array}{l}\text { Wackestone/ } \\
\text { packstone }\end{array}$ & $\begin{array}{l}\text { Pelecypods, peloids, oncoids, } \\
\text { ooids (type } 2 \text { or } 4 \text { ) }\end{array}$ & & \\
\hline \multicolumn{4}{|c|}{ Patch reef subenvironment } \\
\hline Framestone & Microsolenid corals & $\begin{array}{l}\text { Irregularly shaped, unbedded and laterally } \\
\text { limited build-up }\end{array}$ & Microsolenid corals \\
\hline \multicolumn{4}{|c|}{ Open lagoon subenvironment } \\
\hline $\begin{array}{l}\text { Packstone/ } \\
\text { grainstone }\end{array}$ & $\begin{array}{l}\text { Peloids, oncoids, } \\
\text { ooids (type } 1,2 \text { and } 4 \text { ) }\end{array}$ & Bioturbation & $\begin{array}{l}\text { High fossil diversity } \\
\text { (cf. above for details) }\end{array}$ \\
\hline \multicolumn{4}{|c|}{ SHOAL ENVIRONMENT } \\
\hline \multicolumn{4}{|c|}{ Internal shoal subenvironment } \\
\hline \begin{tabular}{l|} 
Active \\
grainstone
\end{tabular} & \multirow{2}{*}{$\begin{array}{l}\text { Dasycladaceans, benthic } \\
\text { foraminifera, lithoclasts, peloids, } \\
\text { oncoids, ooids (type } 1 \text { or } 2 \text { ) }\end{array}$} & & \multirow{2}{*}{$\begin{array}{l}\text { Moderate fossil diversity (ostracods, } \\
\text { pelecypods, gastropods, miliolids, } \\
\text { other benthic foraminifera, } \\
\text { dasycladaceans, sponge spicules) }\end{array}$} \\
\hline $\begin{array}{l}\text { Inactive } \\
\text { packstone/ } \\
\text { grainstone }\end{array}$ & & Encrustation, bioturbation & \\
\hline \multicolumn{4}{|c|}{ External shoal subenvironment } \\
\hline \begin{tabular}{l|} 
Active \\
grainstone
\end{tabular} & \multirow{2}{*}{$\begin{array}{l}\text { Lithoclasts, peloids, } \\
\text { ooids (type 2, } 3 \text { and/or } 4 \text { ) }\end{array}$} & Cross-bedding & \multirow{2}{*}{$\begin{array}{l}\text { High fossil diversity (ostracods, } \\
\text { pelecypods, gastropods, } \\
\text { miliolids, other benthic foraminifera, } \\
\text { dasycladaceans, sponge spicules, } \\
\text { abundant echinoderms) }\end{array}$} \\
\hline $\begin{array}{l}\text { Inactive } \\
\text { grainstone }\end{array}$ & & Encrustation, bioturbation, microbial colonisation & \\
\hline
\end{tabular}

Fig. 4. Depositional environments and sub-environments defined in the Kimmeridgian of the central Swiss Jura according to texture, main constituents, fabrics and diagenetic features, and fossil content. 


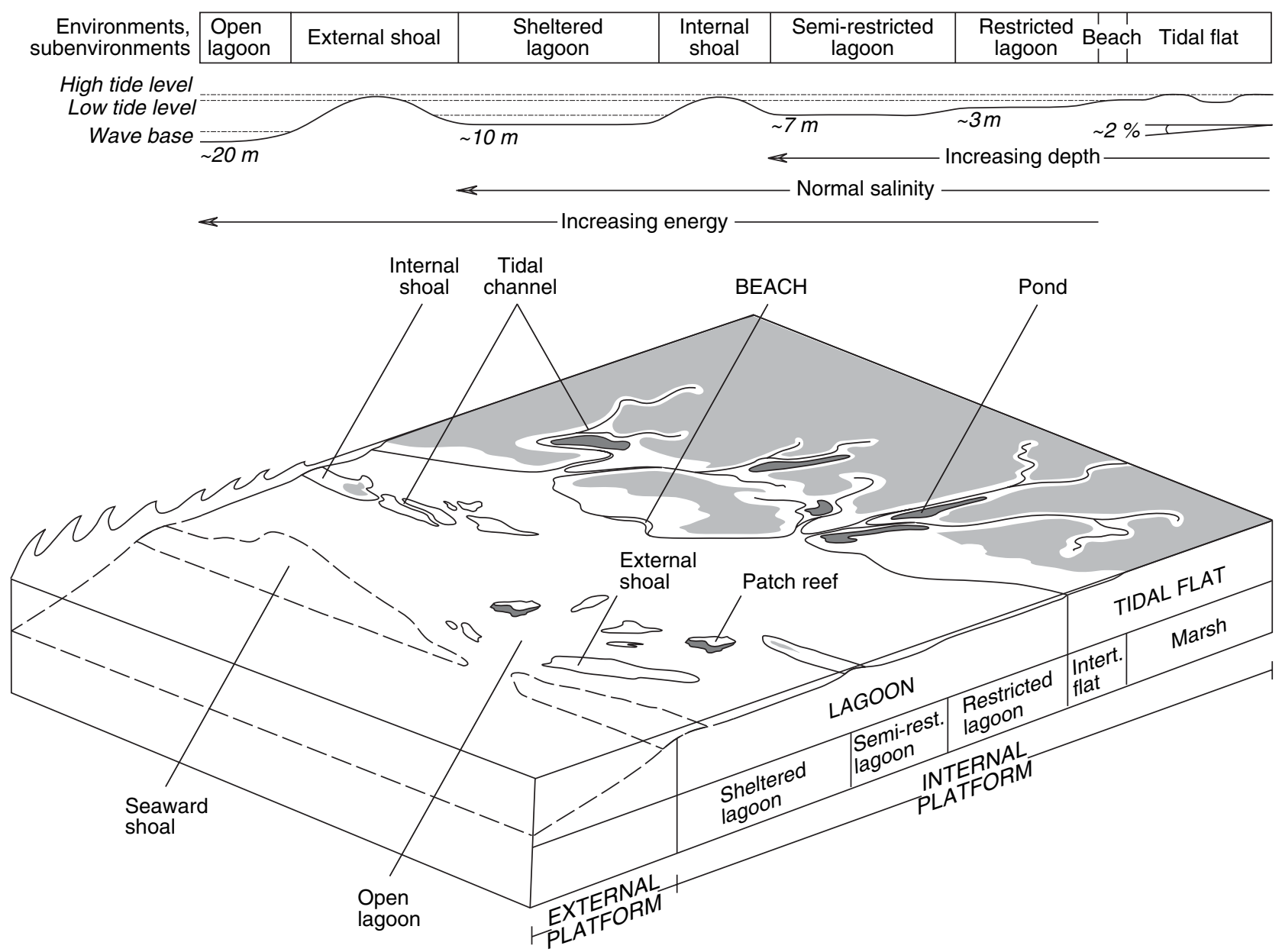

Fig. 5. Spatial distribution of the depositional environments defined in the Kimmeridgian of the central Swiss Jura.

lower intertidal to supratidal zones (Laporte, 1967; Hardie \& Ginsburg, 1977; Shinn, 1983). In the Reuchenette Formation, superimpositions of planar and slightly wavy stromatolites are common. The latter are generally associated with numerous desiccation features and may locally evolve into tepees. These successions probably result from alternating sub-aerial exposure and flooding of the upper intertidal to supratidal zones. Lack of fossils, or low-diversity assemblages, including ostracods, pelecypods, and miliolids, indicate depositional environments that are particularly subject to variable salinity. The absence of evaporite pseudomorphs suggests humid to semi-arid climatic conditions associated with a marsh rather than a sabkha.

\section{Pond sub-environment}

Gyrogonites and stems of charophytes occur locally in bioturbated mudstones with fossils of euryhaline organisms (ostracods, pelecypods, miliolids). They indicate ponds between channel systems that became brackish during periods of heavy rainfall (Shinn et al., 1969; Mojon \& Mouchet, 1992; Joachimski, 1994).

\section{Intertidal flat sub-environment}

Bioturbated mudstones containing alternating micrite and dolomite-rich laminae or alternating micrite and peloid-rich laminae are interpreted as having formed on tidal flats, in the presence of microbial mats. The low-diversity fossil assemblage (ostracods, pelecypods, miliolids) indicates variable salinity; the lack of desiccation features suggests the lower intertidal zone.

\section{Tidal channel sub-environment}

Alternating well-sorted peloid grainstones with planar-oblique bedding and peloid wackestones/ packstones with strong bioturbation are interpreted as corresponding to changing high- and low-energy deposits. These facies are characterized by moderate fossil diversity including ostracods, pelecypods, gastropods, miliolids, other 


\begin{tabular}{|c|c|c|}
\hline \multicolumn{2}{|c|}{ LITHOLOGY } & ALLOCHEMS \\
\hline \multirow{3}{*}{ 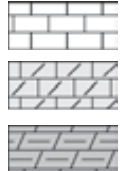 } & Limestone & Skeletal grains \\
\hline & Dolomitic limestone & $\Leftarrow$ Ostracod \\
\hline & \multirow{2}{*}{$\begin{array}{l}\text { Argillaceous and } \\
\text { dolomitic limestone }\end{array}$} & $\smile$ Oyster \\
\hline & & Gastropod \\
\hline \multirow[t]{2}{*}{ 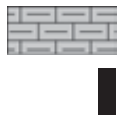 } & $\begin{array}{l}\text { Argillaceous } \\
\text { limestone }\end{array}$ & Serpulid \\
\hline & Dark limestone & bioclast \\
\hline \multicolumn{2}{|c|}{ SED. STRUCTURES } & Undifferentiated \\
\hline & Laminated limestone & $\begin{array}{l}\text { green alga } \\
\text { Marinella }\end{array}$ \\
\hline TT & Chalky limestone & Nerinea \\
\hline \multicolumn{2}{|c|}{ Biogenic structures } & Cladocoropsis \\
\hline & $\begin{array}{l}\text { Undifferentiated } \\
\text { bioturbation }\end{array}$ & $\begin{array}{l}\text { Coral } \\
\text { Brachiopod }\end{array}$ \\
\hline$s$ & Worm tube & Echinoderm \\
\hline \multicolumn{2}{|c|}{ Hydraulic structures } & \multirow{5}{*}{$\begin{array}{cl}\text { Non-skeletal grains } \\
\odot \quad \text { Peloid } \\
\odot \quad \text { Oncoid } \\
\odot \quad \text { Ooid } \\
\text { Black pebble } \\
\text { Lithoclast }\end{array}$} \\
\hline & $\begin{array}{l}\text { Normal graded } \\
\text { bedding }\end{array}$ & \\
\hline \multirow{8}{*}{\multicolumn{2}{|c|}{$\begin{array}{l}\text { Desiccation structures } \\
\qquad \quad \text { Bird's eye } \\
\square \quad \text { Circum-granular crack } \\
4 \quad \text { Desiccation crack }\end{array}$}} & \\
\hline & & \\
\hline & & \\
\hline & & TEXTURE \\
\hline & & M Mudstone \\
\hline & & W Wackestone \\
\hline & & P Packstone \\
\hline & & G Grainstone \\
\hline
\end{tabular}

Fig. 6. Legend for the studied sections.

benthic foraminifera, dasycladaceans and sponge spicules. Dasycladaceans and sponge spicules, usually characteristic of more marine condition, are probably reworked and reflect an intermediate position between coastal and shallow marine environments. Sponge spicules are predominantly rhaxes from the siliceous sponge Rhaxella (Dupraz, 1999).

\section{Beach environment}

Peloid and oncoid packstones/grainstones with planar bedding and keystone vugs occur at the base of the Reuchenette Formation in the Gorges de Court section. Keystone vugs are generally preserved immediately above the wave swash zone on high-energy beaches (Inden \& Moore, 1983). In the studied sections, oncoids are generally elliptical, micritic throughout, and locally coated by a thin and concentric lamina of darker micrite. Average size is around $1.5 \mathrm{~mm}$. A millimetre-thick calcrete clast appears in the same stratigraphic interval and suggests that the base of the Reuchenette Formation was deposited under a semi-arid climate (Esteban \& Klappa,
1983; Wright, 1994). Evaporite pseudomorphs in the underlying Verena Member support this interpretation (Hug, 2003).

\section{Lagoonal environment}

\section{Restricted lagoon sub-environment}

Bioturbated mudstones with clear dolomite rhombohedrons $(0.2 \mathrm{~mm}$ on average), gypsum pseudomorphs, and low fossil diversity (ostracods, pelecypods, and miliolids) that do not display desiccation features or stromatolitic laminations indicate low water energy and variable salinity. Dolomite crystals are commonly scattered in the matrix. Gypsum pseudomorphs appear only once, in the Péry-Reuchenette section, and may reflect a temporary more arid climate. Small-sized (diameter between 20 and $150 \mu \mathrm{m}$ ) hollow spherical microfossils exhibiting micritic or sparitic thin walls occur locally. These calcispheres probably correspond to the reproductive cysts of dasycladaceans of the sub-family Acetabulariae that live in restricted to semirestricted lagoons (Marszalek, 1975) and not to calcareous dinoflagellate cysts (Keupp, 1991). Well-sorted peloidal grainstones occur locally and imply episodic high-energy events.

\section{Semi-restricted lagoon sub-environment}

Bioturbated mudstones and wackestones with moderate fossil diversity (ostracods, pelecypods, gastropods, miliolids, other benthic foraminifera, dasycladaceans, and sponge spicules) are attributed to semi-restricted lagoons. Calcispheres are abundant. Bacinella irregularis, Cayeuxia (Dupraz, 1999), Marinella lugeoni (Leinfelder \& Werner, 1993), Thaumatoporella (Bolliger \& Burri, 1970; Leinfelder et al., 1993), and Cladocoropsis mirabilis (Turnsek et al., 1981; Flügel, 1982; Jansa et al., 1982; Termier et al., 1985) occur locally. The semi-restricted lagoon deposits may contain ooids, which are classified according to Strasser (1986). Type 1 ooids are well rounded, micritic, with thinly laminated cortices; type 2 ooids are irregular, micritic, with thinly laminated cortices; type 4 ooids contain few fine radial laminae. Well-sorted peloidal grainstones alternating with micrite layers occur locally and imply episodic high-energy events.

\section{Sheltered lagoon sub-environment}

The sheltered lagoon sub-environment still corresponds to low-energy deposits (bioturbated wackestones to wackestones/packstones) but differs from the semi-restricted lagoon sub-environ- 
ment in that it contains a high fossil diversity (ostracods, pelecypods, gastropods, miliolids, other benthic foraminifera, dasycladaceans, sponge spicules, and abundant echinoderms), which reflects normal salinity. Bacinella irregularis, Cayeuxia, Marinella lugeoni, and Cladocoropsis mirabilis are common. Ooids of type 2 or 4 occur locally.

\section{Patch-reef sub-environment}

An irregularly shaped, unbedded, and laterally limited bioherm of up to 5 metres thick occurs in the upper part of the Reuchenette Formation in the Gorges de Court section. It is mainly composed of microsolenid corals and interpreted as an isolated patch-reef. This bioherm is enclosed in peloid wackestones/packstones with high fossil diversity (ostracods, pelecypods, gastropods, miliolids, other benthic foraminifera, dasycladaceans, sponge spicules, and abundant echinoderms) that indicate a sheltered lagoon sub-environment.

\section{Open lagoon sub-environment}

Bioturbated packstones to packstones/grainstones with peloids, oncoids, ooids and/or high fossil diversity (ostracods, pelecypods, gastropods, miliolids, other benthic foraminifera, dasycladaceans, sponge spicules and abundant echinoderms) indicate moderate to high water energy and fully marine conditions. Type 1,2 and 4 ooids occur with type 2 being dominant.

\section{Shoal environment}

Grainstones with dasycladaceans, benthic foraminifera, lithoclasts, peloids, oncoids, and/or ooids are interpreted as having formed on shoals. High fossil diversity (ostracods, pelecypods, gastropods, miliolids, other benthic foraminifera, dasycladaceans, sponge spicules, and abundant echinoderms) points to external shoals in contact with the open sea, whereas moderate fossil diversity (ostracods, pelecypods, gastropods, miliolids, other benthic foraminifera, dasycladaceans, and sponge spicules) implies shoals within the lagoon. Internal shoals contain type 1 or 2 ooids, whereas type 2,3 , and/or 4 ooids are common in external shoals. Type 3 includes ooids with thinly laminated fine-radial cortices (Strasser, 1986). Cross-bedding suggests rapid sediment burial of active shoals. Inactive shoals are bioturbated and contain hardgrounds reflecting low sedimentation rates or sediment bypass. The hardgrounds are mostly micritic layers inter- preted as microbial films. They may be encrusted by serpulids, calcareous sponges, Cayeuxia, Troglotella, and/or Lithocodium (Wernli \& Fookes, 1992; Schmid \& Leinfelder, 1996; Dupraz, 1999). Micritic alveolar-septal structures occur locally in pore spaces and are attributed to filamentous chasmoliths (Hillgärtner et al., 2001).

\section{DEPOSITIONAL SEQUENCES AND HIERARCHICAL STACKING PATTERNS}

A depositional sequence is a relatively conformable succession of genetically related strata bounded by unconformities and their correlative conformities (Mitchum, 1977). In the Kimmeridgian of the Swiss Jura, the evolution through time of sedimentary facies and bed thicknesses allows the definition of several orders of depositional sequences: small-, medium- and large-scale sequences that are hierarchically stacked (Fig. 7). Independent of scale, bounding surfaces and deepening-shallowing facies trends suggest that sequence formation was at least partly controlled by accommodation changes and thus permit an interpretation in terms of sequence stratigraphy (Strasser et al., 1999). However, because the geometry of the sedimentary bodies cannot be defined in isolated sections, lowstand, transgressive and highstand deposits rather than systems tracts (Vail et al., 1991) are referred to. Moreover, because of high-frequency sea-level fluctuations superimposed on a lower-frequency sea-level change, small-scale sequence boundaries, transgressive surfaces, or maximum-flooding surfaces may be repeated. In such cases, it is adequate to speak of sequence-boundary zones, transgressivesurface zones, or maximum-flooding zones respectively (Montañez \& Osleger, 1993; Osleger \& Montañez, 1996; Strasser et al., 1999). The sequential interpretation of the Kimmeridgian in the central Swiss Jura reveals that the expression of the small-, medium-, and large-scale sequences varies according to their position inside a lowerfrequency sequence. In particular, they seem to be greatly controlled by the second-order transgression, which starts in the Late Oxfordian and ends in the Late Kimmeridgian (Hardenbol et al., 1998).

\section{Diagnostic sedimentological features}

The fourth medium-scale sequence of the Gorges $\mathrm{du}$ Pichoux section is used here to illustrate sequence-stratigraphic interpretation (Fig. 7). The 


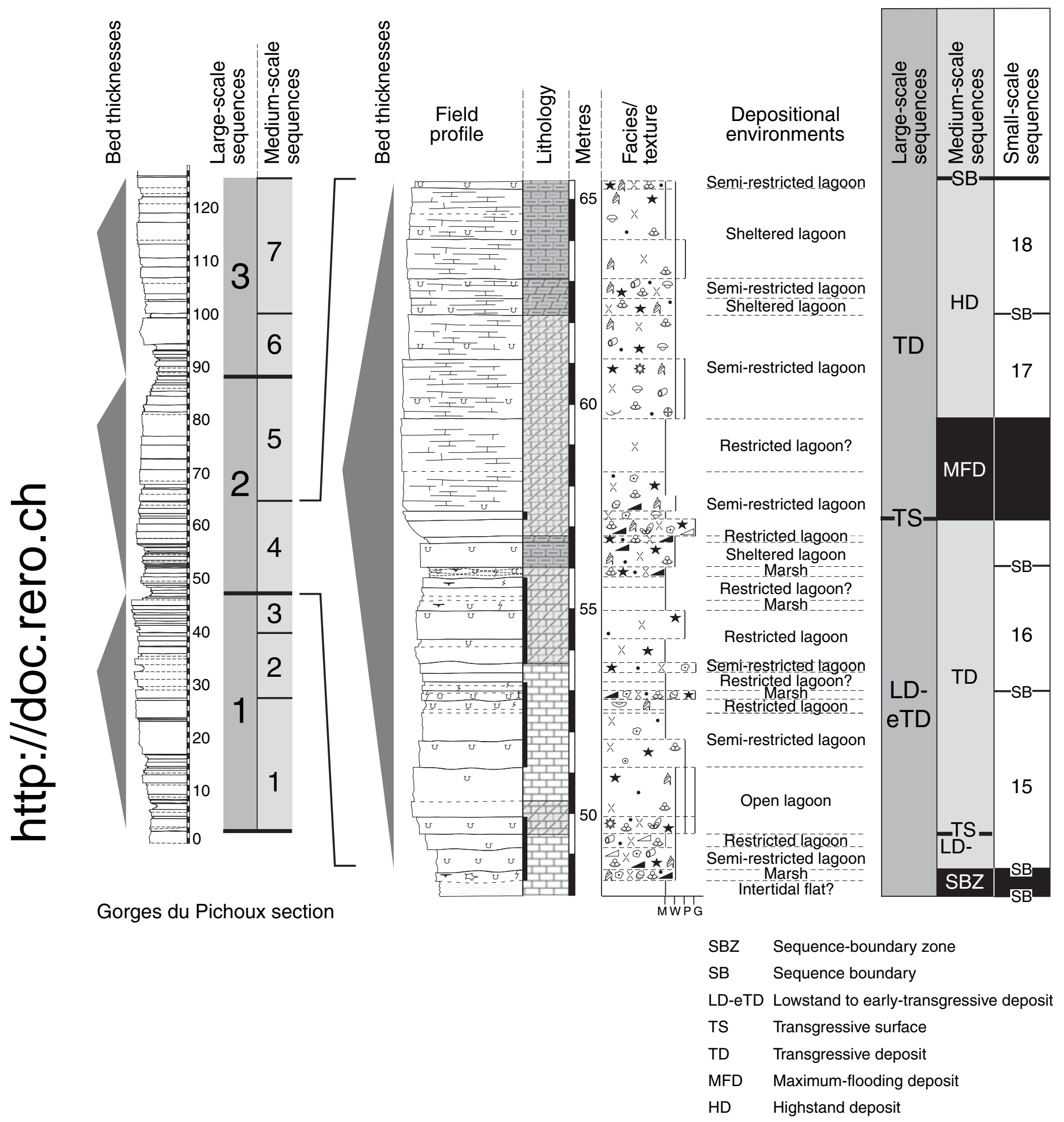

Fig. 7. Different orders of depositional sequences defined in the Kimmeridgian of the central Swiss Jura according to the evolution through time of bed thickness and sedimentary facies. Large-, medium- and small-scale sequences are hierarchically stacked.

lower part of the fourth sequence includes thin beds with laminations and desiccation features that indicate low accommodation. Moreover, encrusters such as serpulids and intense biotur- bation reveal low accumulation rates. On shallow carbonate platforms, low accommodation and low accumulation rates are characteristic of lowstand and early transgressive periods. Conse- 
quently, the lower part of the fourth mediumscale sequence in the Gorges du Pichoux section is interpreted as a lowstand to early transgressive deposit (LD-eTD). Repetitive erosive bed surfaces overlain by lithoclasts, black pebbles, and mixed freshwater and marine fossils point to higherfrequency sea-level fluctuations, which are superimposed on the medium-scale LD-eTD. The fact that the erosive surfaces never cut deeply into the substrate and that the lowstand to early-transgressive deposits are relatively thick suggests that the short-term sea-level drops were attenuated by the second-order transgression (Strasser et al., 1999).

Thicker beds, a textural change from wackestone to packstone, and a greater fossil diversity indicate a relative sea-level rise and a shift to more open depositional environments. This shift may have been rapid and defines a transgressive surface (TS).

Overlying, moderately thick beds with mostly sub-tidal facies indicate an increase in accommodation rate. Furthermore, high content of quartz, clays, and plant debris testify to an increased terrigenous input. Increased accommodation rate and terrigenous input are interpreted as characteristic of transgressive deposits (TD). Beds with black pebbles and charophytes indicate emersions resulting from superimposed higher-frequency sea-level fluctuations, and correspond to the sequence boundaries of small-scale sequences 15 and 16 (Fig. 7).

The thickest beds suggest the highest accommodation gain. Together with the most openmarine depositional environments they imply maximum-flooding conditions. In the studied sections, maximum-flooding surfaces generally are difficult to distinguish, and an interval of maximum-flooding deposits (MFD) is instead identified. The upper part of the fourth mediumscale sequence in the Gorges du Pichoux section is characterized by a decrease in bed thickness, which indicates loss of accommodation space during highstand conditions (HD). Finally, the thinnest beds and the most restricted depositional environments occur at the top of this sequence and indicate the fastest fall in relative sea level. These beds correspond to the sequence boundary (SB).

\section{Small-scale sequences}

In the Kimmeridgian of the central Swiss Jura, small-scale depositional sequences are 0.5-15 m thick and composed of one to nine beds (Figs 7 and 8). Sequences bounded by flooding surfaces (characterized by an increase in bed thickness, a textural change, greater fossil diversity, a high percentage of quartz, clays and plant debris, and evidence for reworking such as lithoclasts, black pebbles and mixed freshwater and marine fossils) are dominant. This is explained by the general transgressive trend on which these sequences are superimposed (Strasser et al., 1999). They show shallowing-up or deepening-shallowing trends of facies evolution. Shallowing-up sequences are characterized by thinning-up beds and depositional environments becoming more restricted towards the top. Their occurrence seems to be independent of their position in a medium- or large-scale sequence. The lower part of deepening-shallowing sequences contains thickeningup beds and a facies evolution towards more open depositional environments, whereas the upper part is characterized by a shallowing-up trend. Deepening-shallowing sequences usually occur in the transgressive or maximum-flooding intervals of medium-scale sequences where accommodation gain was high.

Sequences bounded by sub-aerial exposure surfaces (indicated by desiccation features) are scarce. They generally appear in late highstand deposits of large-scale sequences where accommodation was low.

In some small-scale sequences, elementary sequences can be defined, which display a shallowing-up facies evolution (Fig. 8). They can be compared with the elementary sequences of Strasser et al. (1999), or to the genetic sequences defined by Homewood et al. (1992). Identifiable elementary sequences generally appear close to large-scale sequence boundaries where accommodation space was greatly reduced. Elsewhere, probably because of the second-order transgression, accommodation was too high to record high-frequency, low-amplitude sea-level fluctuations.

\section{Medium-scale sequences}

As a result of the Late Jurassic second-order transgression, asymmetric medium-scale sequences, showing a well-developed transgressive interval and a less well-developed regressive interval, are dominant. Transgressive deposits of medium-scale sequences commonly contain thin beds with bird's eyes and desiccation cracks, indicating intertidal to supratidal depositional environments. Especially in the lowstand to early-transgressive deposits of large-scale 
Fig. 8. Example of deepeningshallowing small-scale depositional sequence bounded by flooding surfaces. Such sequences commonly appear in transgressive or maximum-flooding intervals of medium-scale sequences, when accommodation is high.

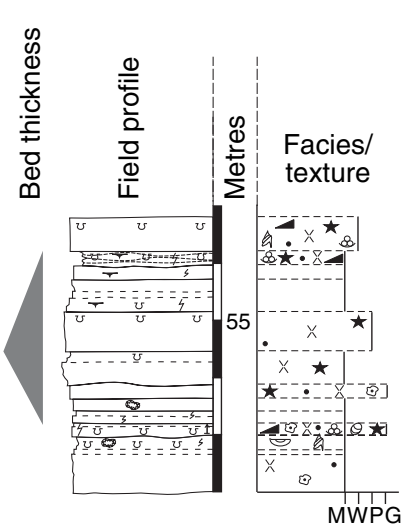

Gorges du Pichoux section

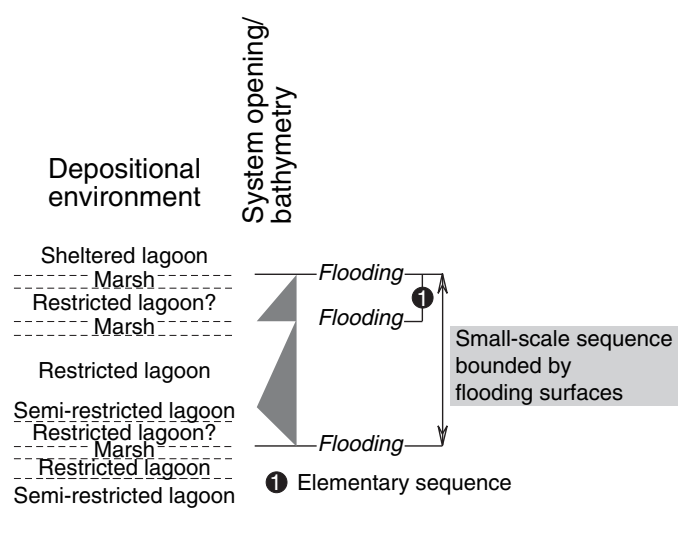

favoured the development of microencrusters, which are commonly observed in the MFD of medium-scale sequences (Neuweiler et al., 1996; Dupraz \& Strasser, 1999).

\section{Definition of large-scale sequences and correlation of the studied sections}

Two distinct lithological units are identified in each of the three studied sections (Fig. 9). The lower unit is characterized by thin to moderately thick beds, a relatively high content of siliciclastics, many desiccation structures, and dolomite. This interval displays two general deepening-shallowing trends that are interpreted as the first two large-scale sequences (corresponding to parts $A$ and $B$ in Fig. 9), which in turn consist of the first five medium-scale sequences. The upper boundary of these largescale sequences corresponds to an interval of relatively thin and marly beds that is expressed as depressions in the weathering profile (Fig. 9). Because of the Late Jurassic second-order transgression, the first two large-scale sequences are asymmetric, showing a well-developed transgressive interval and a less well-developed regressive interval (Einsele \& Bayer, 1991). Nevertheless, the upper part of the first large-scale sequence is characterized by a thinning-up of medium- and small-scale sequences and a shift to more restricted depositional environments. This loss of accommodation results probably from a superimposed higher-frequency sea-level fall as well as from the healthy carbonate productivity that was able to catch up and keep up with the second-order sea-level rise (Kendall \& Schlager, 1981; Jones \& Desrochers, 1992; Posamentier et al., 1992; Handford \& Loucks, 1994; Hunt \& Tucker, 1995). 


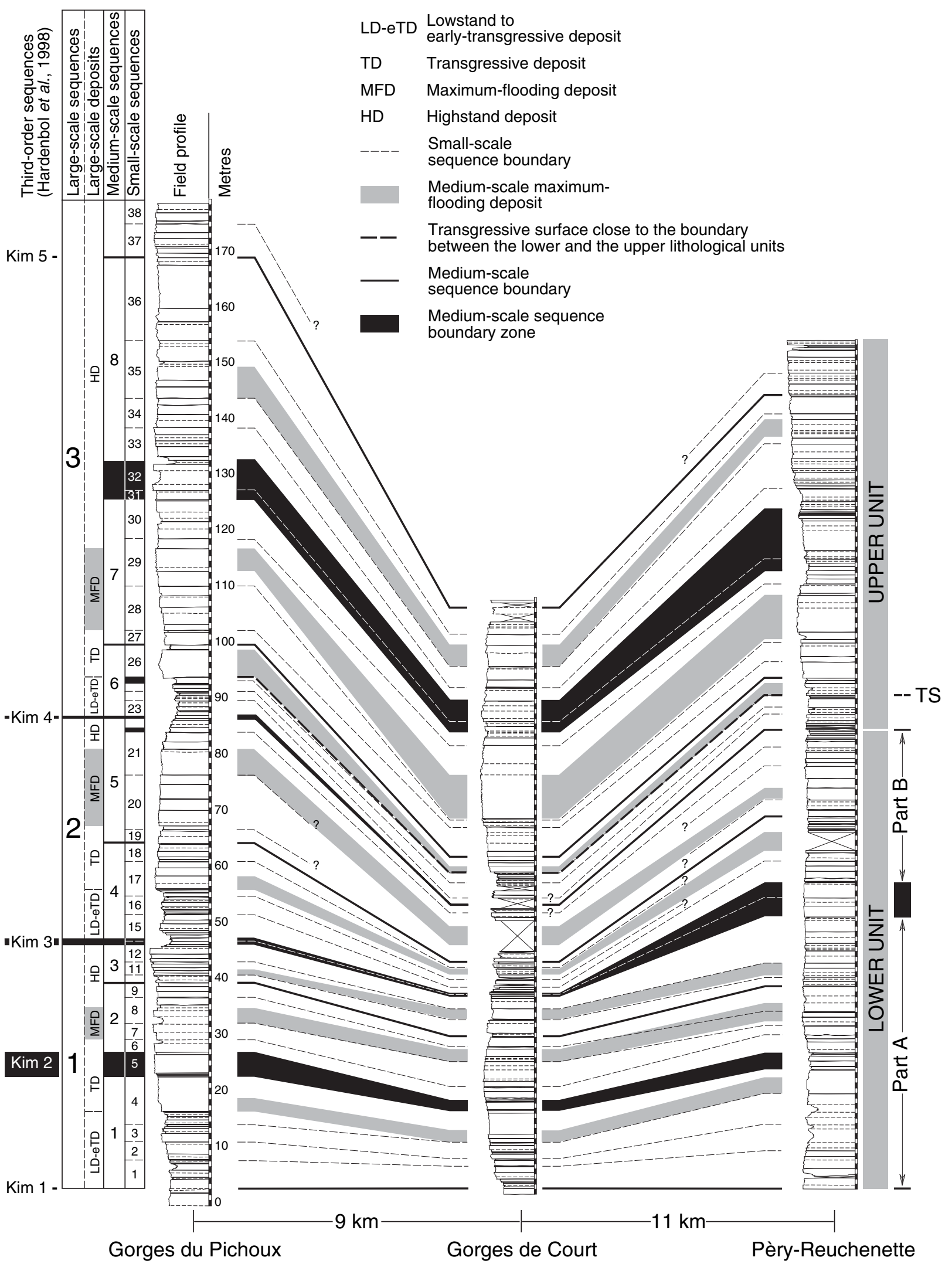

Fig. 9. Correlation of the studied sections. A lower unit, which contains parts A and B, and an upper unit are distinguished. These three intervals correspond to large-scale sequences. 
The upper unit of the Kimmeridgian in the central Swiss Jura is characterized by thick beds of massive limestone and the quasi-disappearance of terrigenous material, desiccation structures, and dolomite. Conversely, carbonate-producing organisms such as green algae and corals are common. This interval corresponds to a general deepening-shallowing trend that is interpreted as the third large-scale sequence, including mediumscale sequences 6 to 8 (Fig. 9).

No major hiatuses have been detected in the three studied sections, which is in accordance with the general transgressive trend and greenhouse conditions during the Kimmeridgian: low amplitudes of high-frequency sea-level fluctuations could not create deep erosion (Read et al., 1995). Moreover, carbonate production and accumulation were sufficient to constantly fill the created accommodation space. Finally, the studied sections are essentially composed of low-energy lagoonal deposits, in which lateral facies changes are reduced. The Kimmeridgian of the central Swiss Jura is therefore well-suited for high-resolution sequence-stratigraphic correlation (Fig. 9). Lithologic datum are provided by markers such as the base of the Reuchenette Formation, the 'Marnes à Exogyra virgula', and the 'Calcaires en Plaquettes' of the 'Portlandien' that are presumed to be more or less isochronous at the scale of the studied platform area (Gygi, 2000). In all studied sections, this interval includes three large-scale sequences that contain the same number of medium- and small-scale sequences. This implies that medium- and small-scale sequences are laterally continuous. Thickness changes in the sections are attributed to differential compaction and subsidence.

The boundary between the lower and the upper lithological units defined in the studied sections precedes the most important increase in accommodation that is recorded in the Kimmeridgian of the central Swiss Jura, as indicated by the thick beds and the most open-marine facies in the medium-scale sequence 7 (Fig. 9). The correlation of the platform sections with three biostratigraphically well-dated sections located in the Vocontian Basin in France shows that this major increase in accommodation occurs most probably in the Eudoxus ammonite zone (Late Kimmeridgian) and corresponds to the second-order maximum flooding recorded in most of the other West European basins (Colombié, 2002; Colombié \& Strasser, 2003; Fig. 10).

\section{CYCLOSTRATIGRAPHY}

In order to constrain the time involved in the sedimentary processes reigning on the Jura platform, a cyclostratigraphic analysis of the studied sections has been attempted. The first step involves a sequence-stratigraphic correlation with sections in the Vocontian Basin where biostratigraphic control is excellent (Atrops, 1982; Fig. 10). The base of the Kimmeridgian in the Swiss Jura is a lithostratigraphic marker of regional importance that lies in the Platynota ammonite zone (Gygi \& Persoz, 1986) and corresponds to the first medium-scale sequence boundary. The Swiss Jura sections are correlated with the Vocontian Basin sections relative to this medium-scale sequence boundary, which is also located in the basin successions in the Platynota zone (Atrops, 1982). Furthermore, the number of small-scale sequences counted between two medium-scale sequence boundaries is the same in the basin and on the platform, suggesting that the medium-scale sequences are laterally continuous. Consequently, the medium-scale sequence boundaries recorded on the platform can be correlated with the ones defined in the basin (Fig. 10). The precise biostratigraphy allows the comparison of the sequence-stratigraphic interpretation established in the Swiss Jura and Vocontian Basin with the Late Jurassic sequencechronostratigraphic chart published by Hardenbol et al. (1998), and an estimation of the duration of the different orders of depositional sequences.

In the Tethyan realm, the Kimmeridgian includes five third-order sequence boundaries, Kim 1 to Kim 5 (Hardenbol et al., 1998). In concordance with the ammonite zones defined by Atrops (1982), these third-order sequence boundaries coincide with five of the nine medium-scale sequence boundaries identified in this study (Fig. 11). The La Méouge section, which is the most remote section from the Jura platform, is relatively free of resedimented facies and displays regular marl-limestone alternations and only a few amalgamated limestone beds (Colombié \& Strasser, 2003). There, 97 alternations (i.e. elementary sequences) are counted between the sequence boundaries interpreted as Kim 1 and Kim 4 (Colombié, 2002). According to Hardenbol et al. (1998), this interval corresponds to about $2 \mathrm{Ma}$. Consequently, the duration of a marllimestone alternation is $c a 20 \mathrm{ka}$, which suggests that it formed in tune with the orbital precession cycle (Berger et al., 1989). Furthermore, the detailed analysis of the platform sections (Fig. 7) 

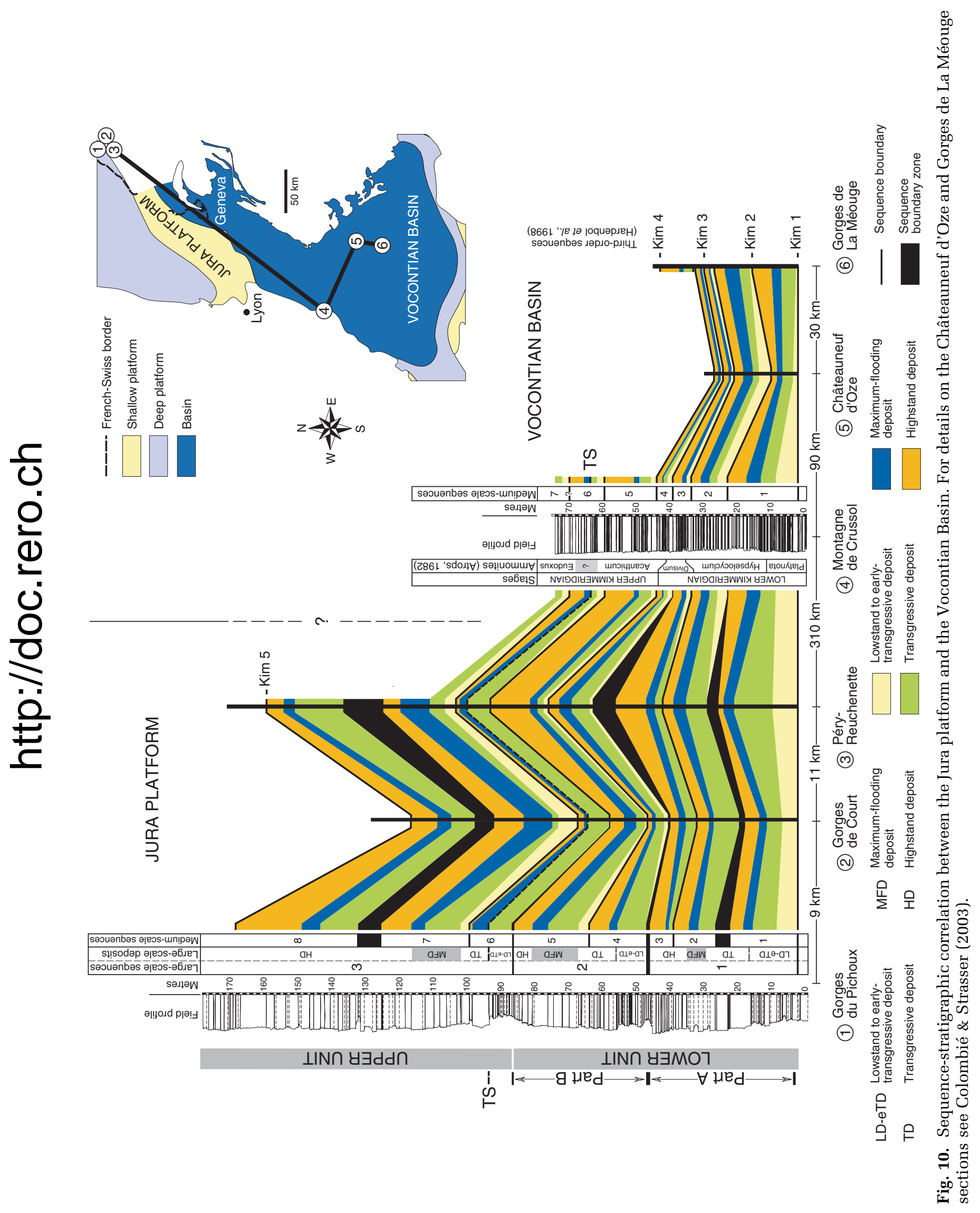
Fig. 11. Comparison of the time spans proposed by Hardenbol et al. (1998) with the ones defined in the Kimmeridgian of the Swiss Jura. Uncertainties in interpretation (*) are discussed in the text.

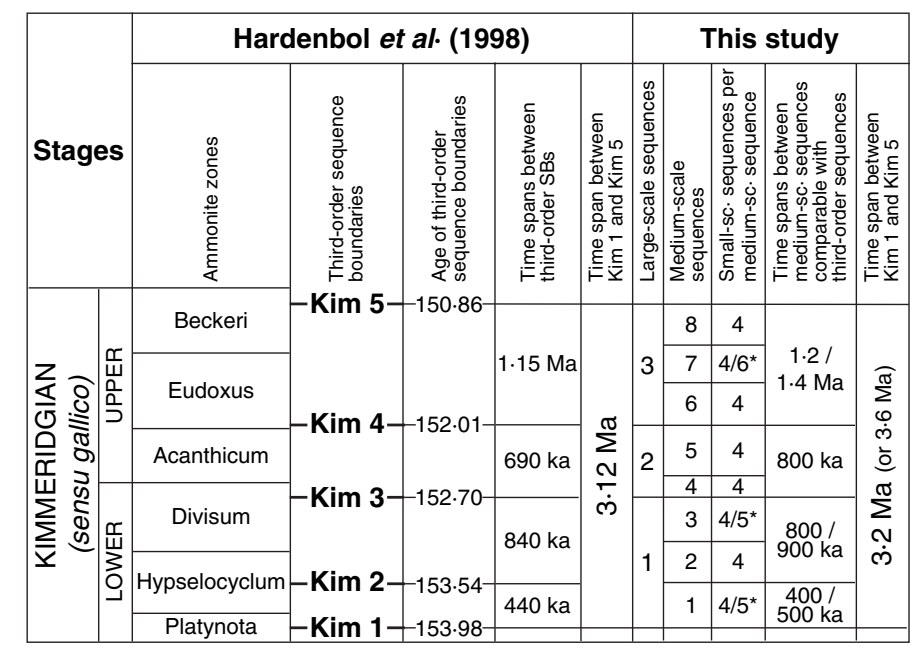

platform-to-basin correlation lead to a biostratigraphically well-constrained temporal framework. In particular, the large-scale and the medium-scale sequences revealed in this study can then be compared with the sedimentary sequences defined in other Western European basins (north-eastern Spain, western and central Portugal, northern France, and southern England; Fig. 12).

The large-scale sequence boundaries, and notably the ones equivalent to Kim 3 and Kim 4, appear in comparable biostratigraphic positions in most of the basins indicated in Fig. 12. In particular, the sequential interpretations proposed by Taylor et al. (2001) in the WessexWeald Basin (southern England) and by Marques \& Olóriz (1989) in the Algarve Basin (Portugal) are very similar to the one proposed in this study. The slight deviations concerning the location of Kim 1, Kim 3, Kim 4 and Kim 5 probably result from uncertainty in the biostratigraphic dating and in the correlations between the Tethyan and the boreal realms.

The sequence-boundary zone between medium-scale sequences 7 and 8 appears distinctly in the central Swiss Jura but is not mentioned in other places. In the central Swiss Jura, mediumscale sequences 7 and 8 belong to the third largescale sequence that contains three medium-scale (i.e. $400 \mathrm{ka}$ ) and 12 small-scale (i.e. $100 \mathrm{ka}$ ) sequences. The third large-scale sequence would therefore represent $1.2 \mathrm{Ma}$ (Fig. 11). This largescale sequence is comprised between third-order sequence boundaries Kim 4 and Kim 5, and Hardenbol et al. (1998) attribute about 1.15 Ma to this interval (Fig. 11). Consequently, the duration of the third large-scale sequence proposed in this study is consistent with the one inferred 


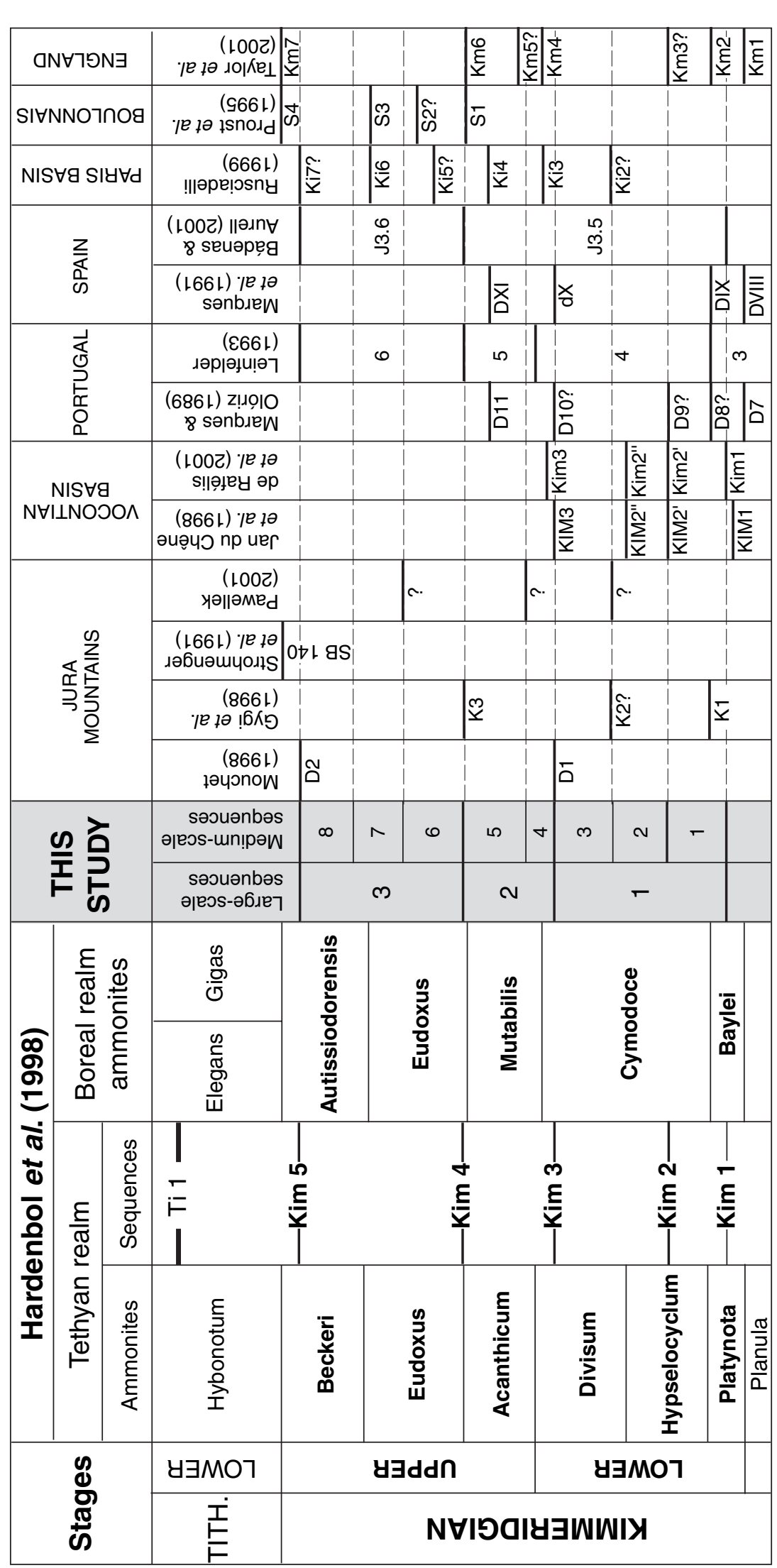

Ð

즘. 의 잉

के

胥

등

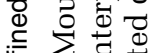

일 㫣

这西

중

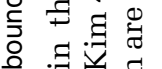

ه 음

क्ष

ठ্

๑

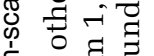

空

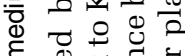

昰 者

음

这 $\leftrightarrows$.

궁켱

उํㅕㄴ

웡혀

के 0 व

寻总总

$\Xi \stackrel{0}{\Xi} \dot{\Xi}$

ن

음ำ

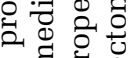

व बै

苞它

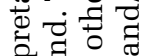

해욤

. 푀.尹 急

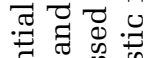

बी

क्ष त्र

制=

$\mp 7 \tilde{D}_{0}$

ఖี

उे क्ष

ㅇ. 켫

है की

สี.

웡

రำ 일

ง 营

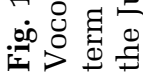


from the sequence-chronostratigraphic chart of Hardenbol et al. (1998). However, it does not include small-scale sequences 31 and 32 that form the sequence boundary zone (SBZ) between medium-scale sequences 7 and 8 (Fig. 9). Moreover, the upper part of the Kimmeridgian is marked by high accommodation that should result in rather homogeneous facies and thick beds. Nevertheless, small-scale sequences 31 and 32 display important facies and thickness variations. The SBZ between medium-scale sequences 7 and 8 is therefore assumed to result at least partly from differential subsidence. Unless enhanced by local or regional tectonics, this medium-scale sequence boundary appears to be attenuated because of the high accommodation rate resulting from the Late Kimmeridgian second-order maximum flooding (Haq et al., 1987; Hallam, 1988, 2001; Jacquin \& de Graciansky, 1998; Taylor et al., 2001; Taylor \& Sellwood, 2002). Kim 2 that is only weakly developed in the central Swiss Jura, also seems difficult to define in the other basins. This sequence boundary is located close to the maximum-flooding interval of the first large-scale sequence defined in this study and is consequently attenuated (Strasser et al., 1999; Fig. 9).

In most of the Western European basins, the Early Kimmeridgian sea-level rise led to relatively high siliclastic input and low sedimentation rates that resulted in marly deposits and condensed sections respectively. Within the Acanthicum ammonite zone, carbonate platform conditions were well established with the local development of reefal facies (Marques \& Olóriz, 1989; Marques et al., 1991; Bádenas \& Aurell, 2001). A regressive trend is generally recognized in the Late Kimmeridgian (Proust et al., 1995; Rusciadelli, 1999). In southern England (Wessex-Weald Basin; Taylor et al., 2001; Taylor \& Sellwood, 2002) and westcentral Portugal (Lusitanian Basin; Leinfelder, 1993), the sedimentary record is greatly controlled by the synsedimentary tectonic regime and the related basin configuration.

In the central Swiss Jura, the Early Kimmeridgian is characterized by a general loss of accommodation up to sequence boundary Kim 3 (Fig. 9). Depositional sequences are laterally continuous and present approximately the same thickness from one section to the other, so that a tectonic control can be excluded. This general accommodation loss is interpreted as resulting from a slowing down of the second-order sealevel rise and from carbonate production and accumulation that were sufficiently influential to maintain keep-up with sea-level rise (Kendall \& Schlager, 1981; Jones \& Desrochers, 1992; Posamentier et al., 1992; Handford \& Loucks, 1994; Hunt \& Tucker, 1995). The second-order trend of sea-level rise subsequently accelerated up to the maximum flooding in the Eudoxus zone that corresponds in the central Swiss Jura to the thickest beds and the most open-marine facies. Consequently, the Early Kimmeridgian of the central Swiss Jura can be classified as part of a keep-up transgressive systems tract that was initiated already in the Late Oxfordian (Fig. 2).

\section{CONCLUSIONS}

1 Field observations and thin-section analyses reveal that in Kimmeridgian times the central Swiss Jura was occupied by tidal flats and by more or less open-marine lagoons where shoals and bioherms developed. Low-energy lagoonal deposits such as mudstones and bioclast-peloid wackestones to packstones are dominant. Higherenergy grainstones composed of bioclasts, peloids, and ooids occur in lesser proportion. On the basis of temporal facies changes and stacking patterns, sequence and cyclostratigraphic interpretations are proposed.

2 Small-, medium- and large-scale depositional sequences are identified. Diagnostic sedimentological features, which are independent of scale, used for the sequence-stratigraphic interpretation are defined. However, the expression of the sequences varies according to sequence position within a lower-frequency depositional sequence. In particular, their formation is strongly controlled by the second-order transgression characterizing the lower part of the Kimmeridgian.

3 The depositional sequences defined in the central Swiss Jura are correlated with biostratigraphically well-dated sections in the Vocontian Basin. This permits comparison with the sequence stratigraphy compiled in the sequencechronostratigraphic chart of Hardenbol et al. (1998). According to this chart, the Kimmeridgian lasted 3.12 Ma (Gradstein et al., 1994). In the central Swiss Jura, this interval includes 32 small-scale and eight medium-scale sequences suggesting that the small-scale and the mediumscale sequences correspond to the first and the second eccentricity cycles, respectively (i.e. 100 and $400 \mathrm{ka}$ ). The high-resolution platform-tobasin correlation thus reveals that the platform and basin dynamics were at least partly controlled by cyclic environmental changes induced 
by insolation variations in the Milankovitch frequency band.

4 This high-resolution temporal framework constitutes a solid base to compare the sequencestratigraphic interpretation established in the central Swiss Jura with the one proposed for other Western European basins, and to define the controlling factors for platform development. The correlation of the studied platform sections reveals two distinct lithological units. The lower unit is composed of deposits between sequence boundaries Kim 1 and Kim 4 and exhibits thinly bedded limestones with siliciclastics and desiccation features. The second unit lies between sequence boundaries Kim 4 and Kim 5 and is characterized by thickly bedded limestones, relatively open-marine facies, as well as the quasi-disappearance of siliciclastic sediments and desiccation features. The boundary between these two units is located near the most important increase in accommodation recorded in the central Swiss Jura during the Kimmeridgian. It occurs in the Eudoxus ammonite zone (Late Kimmeridgian) and corresponds to the second-order maximum flooding recognized in many sedimentary basins. Moreover, the large-scale sequence boundaries defined in the Kimmeridgian of the central Swiss Jura appear in comparable biostratigraphic positions in most of Western European basins. Discrepancies that occur are probably because of local or regional tectonics. Lastly, the Early Kimmeridgian sea-level rise led to the formation of marly intervals and condensed sections in most of the Western European basins. In contrast, carbonate production and accumulation on the Jura platform were sufficiently influential to maintain keep-up with the second-order transgression.

\section{ACKNOWLEDGEMENTS}

This study is part of a research project funded by the Swiss National Foundation (no. 20-56491.99). This financial support is gratefully acknowledged. We also thank reviewers M.T. Harris, B. Bádenas, and P. Blanchon, and co-editor I.P. Monañez who helped to improve the manuscript by their helpful and useful comments.

\section{REFERENCES}

Atrops, F. (1982) La sous-famille des Ataxioceratinae (Ammonitina) dans le Kimméridgien inférieur du Sud-Est de la France. Systématique, évolution, chronostratigraphie des genres Orthosphinctes et Ataxioceras. Doc. Lab. Géol. Lyon, 83, 463.

Aubert, D. (1932) Un niveau à Exogyra virgula, Defr. à la Vallée de Joux. Bull. soc. vaud. sc. nat., 57, 477-478.

Aubert, D. (1950) Nouvelles observations sur le niveau à $E_{X}$ ogyra virgula dans le Jura. Bulletin des Laboratoires de Géologie, Minéralogie, Géophysique et du Musée géologique de l'Université de Lausanne, 95, 1-6.

Bádenas, B. and Aurell, M. (2001) Kimmeridgian palaeogeography and basin evolution of northeastern Iberia. Palaeogeogr. Palaeoclim. Palaeoecol., 168, 291-310.

Berger, A., Loutre, M.F. and Dehant, V. (1989) Astronomical frequencies for pre-Quaternary palaeoclimate studies. Terra Nova, 1, 474-479.

Bolliger, W. and Burri, P. (1970) Sedimentologie von SchelfCarbonaten und Beckenablagerungen im Oxfordien des zentralen Schweizer Jura. Beitr. geol. Karte Schweiz (N.F.), $140,96$.

Bosence, D.W.J., Wood, J.L., Rose, E.P.F. and Qing, H. (2000) Low- and high-frequency sea-level changes control peritidal carbonate cycles facies and dolomitization in the Rock of Gibraltar (Early Jurassic, Iberian Peninsula). J. Geol. Soc. London, 157, 61-74.

Colombié, C. (2002) Sédimentologie, stratigraphie séquentielle et cyclostratigraphie du Kimméridgien du Jura suisse et du Bassin vocontien (France): relations plate-forme bassin et facteurs déterminants. GeoFocus, 4, Fribourg, 198.

Colombié, C. and Strasser, A. (2003) Depositional sequences in the Kimmeridgian of the Vocontian Basin (France) controlled by carbonate export from shallow-water platforms. Geobios, 36, 675-683.

Dauwalder, P. and Remane, J. (1979) Etude du banc à Nérinées à la limite "Kimméridgien-Portlandien" dans le Jura Neuchâtelois méridional. Paläont. Z., 53, 163-181.

Dercourt, J., Ricou, L.E. and Vrielynck, B. (1993) Atlas: Tethys Palaeoenvironmental Maps. CCGM, Paris.

Dupraz, C. (1999) Paléontologie, paléoécologie et évolution des faciès récifaux de l’Oxfordien Moyen-Supérieur (Jura suisse et français). GeoFocus, 2, Fribourg, 200.

Dupraz, C. and Strasser, A. (1999) Microbialites and micro-encrusters in shallow coral bioherms (Middle to Late Oxfordian, Swiss Jura Mountains). Facies, 40, 101-130.

Einsele, G. and Bayer, U. (1991) Asymmetry in transgressiveregressive cycles in shallow seas and passive continental margin settings. In: Cycles and Events in Stratigraphy (Eds G. Einsele, W. Ricken and A. Seilacher), pp. 660-681. Springer-Verlag, Berlin.

Enay, R., Contini, D. and Boullier, A. (1988) Le Séquanientype de Franche-Comté (Oxfordien supérieur): datations et corrélations nouvelles, conséquences sur la paléogéographie et l'évolution du Jura et règions voisines. Eclogae geol. Helv., 81, 295-363.

Esteban, M. and Klappa, C.F. (1983) Subaerial exposure environment. In: Carbonate Depositional Environments (Eds A. Scholle, D.G. Bebout and C.H. Moore), AAPG. Mem., 33, 1-54.

Flügel, E. (1982) Microfacies Analysis of Limestones. SpringerVerlag, Berlin, Heidelberg, New York, 633 pp.

Gradstein, F.M., Agterberg, F.P., Ogg, J.G., Hardenbol, J., Van Veen, P., Thierry, J. and Huang, Z. (1994) A Mesozoic time scale. J. Geophys. Res., 99, 24051-24074.

Gygi, R.A. (1995) Datierung von Seichtwassersedimenten des Späten Jura in der Nordwestschweiz mit Ammoniten. Eclogae geol. Helv., 88, 1-58. 
Gygi, R.A. (2000) Integrated stratigraphy of the Oxfordian and Kimmeridgian (Late Jurassic) in northern Switzerland and adjacent southern Germany. Denkschriften der Schweizerischen Akademie der Naturwissenschaften, 104, 151.

Gygi, R.A. and Persoz, F. (1986) Mineralostratigraphy, lithoand biostratigraphy combined in correlation of the Oxfordian (Late Jurassic) formations of the Swiss Jura range. Eclogae geol. Helv., 79, 385-454.

Gygi, R.A., Coe, A.L. and Vail, P.R. (1998) Sequence stratigraphy of the Oxfordian and Kimmeridgian stages (Late Jurassic) in northern Switzerland. In: Mesozoic and Cenozoic Sequence Stratigraphy of European Basins (Eds P.-C. de Graciansky, J. Hardenbol, T. Jacquin and P.R. Vail), Soc. Econ. Paleontol. Mineral., Spec. Publ., 60, 527-544.

Häfeli, C. (1966) Die Jura Kreide-Grenzschichten im Bielerseegebiet (Kt. Bern). Eclogae geol. Helv., 59, 565-595.

Hallam, A. (1985) A review of Mesozoic climates. J. Geol. Soc. London, 142, 433-445.

Hallam, A. (1988) A reevaluation of Jurassic eustasy in the light of new data and the revised Exxon curve. In: Sea Level Changes: An Integrated Approach (Eds C.K. Wilgus, B.S. Hastings, C.G. Kendall, H.W. Posamentier, C.A. Ross and J.C. van Wagoner), SEPM Spec. Publ., 42, 261-273.

Hallam, A. (2001) A review of the broad pattern of Jurassic sealevel changes and their possible causes in the light of current knowledge. Palaeogeogr. Palaeoclim. Palaeoecol., 167, 23-37.

Hallock, P. and Schlager, W. (1986) Nutrient excess and the demise of coral reefs and carbonate platforms. Palaios, 1, 389-398.

Handford, C.R. and Loucks, R.G. (1994) Carbonate depositional sequences and systems tracts-responses of carbonate platforms to relative sea-level changes. In: Carbonate Sequence Stratigraphy (Eds R.G. Loucks and J.F. Sarg), AAPG Mem., 57, 3-41.

Haq, B.U., Hardenbol, J. and Vail, P.R. (1987) Chronology of fluctuating sea levels since the Triassic (250 million years ago to present). Science, 235, 1156-1167.

Hardenbol, J., Thierry, J., Farley, M.B., Jacquin, T., de Graciansky, P.-C. and Vail, P.R. (1998) Jurassic chronostratigraphy. In: Mesozoic and Cenozoic Sequence Stratigraphy of European Basins (Eds P.-C. de Graciansky, J. Hardenbol, T. Jacquin and P.R. Vail), SEPM Spec. Publ., 60, (chart).

Hardie, L.A. and Ginsburg, R.N. (1977) Layering; the origin and environmental significance of lamination and thin bedding. John Hopkins University, Studies in Geology, Sedimentation on the modern carbonate tidal flats of northwest Andros Island, Bahamas, 22, 50-123.

Hillgärtner, H., Dupraz, C. and Hug, W. (2001) Microbially induced cementation of carbonate sands: are micritic meniscus cements good indicators of vadose diagenesis? Sedimentology, 48, 117-131.

Homewood, P.W. (1996) The carbonate feedback system: interaction between stratigraphic accommodation, ecological succession and the carbonate factory. Bull. Soc. géol. Fr., 167, 701-715

Homewood, P., Guillocheau, F., Eschard, R. and Cross, T.A. (1992) Corrélations haute résolution et stratigraphie génétique: une démarche intégrée. Bull. Cent. Rech. Explor.Prod. Elf-Aquitaine, 16, 357-381.

Hug, W.A. (2003) Sequenzielle Faziesentwicklung der Karbonatplattform des Schweizer Jura im Späten Oxford und Frühesten Kimmeridge. GeoFocus, 7, 154.

Hunt, D. and Tucker, M.E. (1995) Stranded parasequences and the forced regressive wedge systems tract: deposition during base-level fall-reply. Sed. Geol., 95, 147-160.
Inden, R.F. and Moore, C.H. (1983) Beach environment. In: Carbonate Depositional Environments (Eds A. Scholle, D.G. Bebout and C.H. Moore), AAPG Mem., 33, 211-265.

Jacquin, T. and de Graciansky, P.-C. (1998) Major transgressive-regressive cycles: the stratigraphic signature of European basin development. In: Mesozoic and Cenozoic Sequence Stratigraphy of European Basins (Eds P.-C. de Graciansky, J. Hardenbol, T. Jacquin and P.R. Vail), Soc. Econ. Paleontol. Mineral., Spec. Publ., 60, 15-29.

James, N.P. (1997) The cool-water carbonate depositional realm. In: Cool-water Carbonates (Eds N.P. James and J.A.D. Clarke), SEPM Spec. Publ., 56, 1-20.

Jan du Chêne, R., Atrops, F., Emmanuel, L., de Rafélis, M. and Renard, M. (1998) Palynology, ammonites and sequence stratigraphy from Tethyan Middle Oxfordian to Lower Kimmeridgian, S-E France. Comparison with the Boreal realm. Bull. Centre Rech. Elf Explor. Prod., 22, 273-321.

Jansa, L.F., Termier, G. and Termier, H. (1982) Les biohermes à algues, spongiaires et coraux des séries carbonatées de la flexure bordière du "palaeoshelf" au large du Canada oriental. Revue de Micropaléontologie, 25, 181-219.

Joachimski, M.M. (1994) Subaerial exposure and deposition of shallowing-upward sequences: evidence from stable isotopes of Purbeckian peritidal carbonates (basal Cretaceous), Swiss and French Jura Mountains. Sedimentology, 41, 805824.

Jones, B. and Desrochers, A. (1992) Shallow platform carbonates. In: Facies Models, Response to Sea Level Change (Eds R.G. Walker and N.P. James), Geol. Assoc. Canada, GeoText, 1, 277-301.

Kendall, C.G.St.C. and Schlager, W. (1981) Carbonates and relative changes in sea level. Mar. Geol., 44, 181-212.

Keupp, H. (1991) Fossil calcareous dinoflagellate cysts. In: Calcareous Algae and Stromatolites (Ed. R. Riding), pp. 267-286. Springer-Verlag, Berlin.

Laporte, L.F. (1967) Carbonate deposition near mean sea-level and resultant facies mosaic: Manlius Formation (Lower Devonian) of New York State. AAPG Bull., 51, 73-101.

Leinfelder, R.R. (1993) A sequence stratigraphic approach of the Upper Jurassic mixed carbonate-siliclastic succession of the central Lusitanian Basin. Portugal Profil, 5, 119-140.

Leinfelder, R.R. and Werner, W. (1993) Systematic position and palaeoecology of the Upper Jurassic to Tertiary Marinella lugeoni Pfender. Zitteliana, 20, 105-122.

Leinfelder, R.R., Nose, M., Schmid, D.U. and Werner, W. (1993) Microbial crusts of the Late Jurassic: composition, palaeoecological significance and importance in reef construction. Facies, 29, 195-230.

Marques, B. and Olóriz, F. (1989) La plate-forme de l'Algarve au Jurassique supérieur: les grandes discontinuités stratigraphiques. Cuad. Geol. Iberica, 13, 237-249.

Marques, B., Olóriz, F. and Rodriguez-Tovar, F.J. (1991) Interactions between tectonics and eustasy during the Upper Jurassic and lowermost Cretaceous. Examples from the south of Iberia. Bull. Soc. géol. France, 162, 1109-1124.

Marszalek, D. (1975) Calcisphere ultrastructure and skeletal aragonite from the alga Acetabularia antillana. J. Sed. Petrol., 45, 266-271.

Meyer, C.A. (1993) A sauropod dinosaur megatracksite from the Late Jurassic of northern Switzerland. Ichnos, 3, 29-38.

Meyer, C.A. (1994) A new sauropods printsite from the Upper Jurassic of northern Switzerland ("Kimmeridgian"; Montbautier, Kt. Bern) by Ph. Mouchet - a reply. Revue de Paléobiologie, 13, 427-428. 
Meyer, C.A. and Pittman, J.G. (1994) A comparison between the Brontopodus ichnofacies of Portugal, Switzerland and Texas. In: Aspects of Sauropod Paleobiology (Eds M.G. Lockley, V.F. dos Santos, C.A. Meyer and A.P. Hunt), GAIA Spec. Vol., 10, 125-133.

Mitchum, J.R.M. (1977) Seismic stratigraphy and global changes of sea level, Part 11: Glossary of terms used in seismic stratigraphy. In: Seismic Stratigraphy: Applications to Hydrocarbon Exploration (Ed. C.E. Payton), AAPG Mem., 26, 205-212.

Mojon, P.O. and Mouchet, P. (1992) Révision et validation de la nouvelle combinaison Echinochara pecki (Mädler) Grambast 1965 (Clavatoracées, Charophytes) d'après les matériaux inédits du Kimméridgien basal du Jura suisse septentrional. Bull. Soc. Neuch. Sci. Nat., 115, 9-21.

Montañez, I.P. and Osleger, D.A. (1993) Parasequence stacking patterns, third-order accommodation events, and sequence stratigraphy of Middle to Upper Cambrian platform carbonates, Bonanza King Formation, southern Great Basin. In: Carbonate Sequence Stratigraphy (Eds R.G. Loucks and J.F. Sarg), AAPG Mem., 57, 305-326.

Montañez, I.P. and Read, J.F. (1992) Eustatic control on early dolomitization of cyclic carbonatee: evidence from the Early Ordovician Upper Knox Group, Appaachians. GSA Bull., 104, 872-886.

Mouchet, P. (1998) Stratigraphy and mineralostratigraphy of the Kimmeridgian in the central Jura mountains of Switzerland and eastern France. Eclogae geol. Helv., 91, 53-68.

Neuweiler, F., Reitner, J. and Arp, G. (1996) Controlling factors and environmental significance of organomicrite production and buildup development. In: Global and Regional Controls on Biogenic Sedimentation. I. Reef Evolution (Eds J. Reitner, F. Neuweiler and F. Gunkel). Res. Reports. Göttinger Arb. Geol. Paläont., Sb2, 185-192.

Osleger, D.A. and Montañez, I.P. (1996) Cross-platform architecture of a sequence boundary in mixed siliciclasticcarbonate lithofacies, Middle Cambrian, southern Great Basin, USA. Sedimentology, 43, 197-217.

Pawellek, T. (2001) Fazies-, Sequenz-, und Gamma-Ray-Analyse im höheren Malm der Schwäbischen Alb (Sw-Deutschland) mit Bemerkungen zur Rohstoffgeologie (hochreine Kalke). Tübinger Geowiss. Arb. A, 61, 244.

Posamentier, H.W., Allen, G.P., James, D.P. and Tesson, M. (1992) Forced regressions in a sequence stratigraphic framework: concepts, examples, and exploration significance. A.A.P.G. Bull., 76, 1687-1709.

Pratt, B.R. and James, N.P. (1992) Peritidal carbonates. In: Facies Models: Response to Sea-level Change (Eds R.G. Walker and N.P. James), pp. 303-322. Geol. Assoc. Canada, St. John's, NF, Canada.

Proust, J.N., Deconinck, J.F., Geyssant, J.R., Herbin, J.P. and Vidier, J.P. (1995) Sequence analytical approach to the upper Kimmeridgian-lower Tithonian storm-dominated ramp deposits of the Boulonnais (northern France). A landward time-equivalent to offshore marine source rocks. Geol. Rundsch., 84, 255-271.

Qing, H., Bosence, D.W.J. and Rose, E.P.F. (2001) Dolomitization by penesaline sea water in Early Jurassic peritidal platform carbonates, Gibraltar, western Mediterranean. Sedimentology, 48, 153-163.

de Rafélis Saint-Sauveur, M., Emmanuel, L., Renard, M., Atrops, F. and Jan du Chêne, R. (2001) Geochemical characterization (Mn content) of third order eustatic sequences in Upper Jurassic pelagic carbonates of the Vocontian Trough (SE France). Eclogae geol. Helv., 94, 145-152.
Read, J.F., Kerans, C., Weber, L.J., Sarg, J.F. and Wright, F.M. (1995) Milankovitch sea-level changes, cycles, and reservoirs on carbonate platforms in greenhouse and icehouse worlds. Soc. Sediment. Geol. Short Course, 35.

Rusciadelli, G. (1999) Stratigraphie séquentielle et analyse de l'espace disponible du Jurassique supérieur et du Crétacé inférieur du Bassin de Paris. Atti Ticinensi di Scienze della Terra, 8, 3-83.

Schlager, W. (1993) Accommodation and supply: a dual control on stratigraphic sequences. Sed. Geol., 86, 111136.

Schmid, D.U. and Leinfelder, R.R. (1996) The Jurassic Lithocodium aggregatum-Troglotella incrustans foraminiferal consortium. Palaeontology, 39, 21-52.

Schweigert, G. and Callomon, J.H. (1997) Der bauhini-Faunenhorizont und seine Bedeutung für die Korrelation zwischen tethyalem und subborealem Oberjura. Stuttgarter Beitr. Naturk., B(247), 1-69.

Shinn, E.A. (1983) Tidal flat environment. In: Carbonate Depositional Environments (Eds A. Scholle, D.G. Bebout and C.H. Moore), AAPG Mem., 33, 171-210.

Shinn, E.A., Lloyd, R.M. and Ginsburg, R.N. (1969) Anatomy of a modern carbonate tidal-flat, Andros Island, Bahamas. J. Sed. Petrol., 49, 257-272.

Strasser, A. (1986) Ooids in Purbeck limestones (lowermost Cretaceous) of the Swiss and French Jura. Sedimentology, 33, 711-727.

Strasser, A. (1991) Lagoonal-peritidal sequences in carbonate environments: autocyclic and allocyclic processes. In: Cycles and Events in Stratigraphy (Eds G. Einsele, W. Ricken and A. Seilacher), pp. 709-721. Springer-Verlag, Berlin.

Strasser, A. and Davaud, E. (1983) Black pebbles of the Purbeckian (Swiss and French Jura): lithology, geochemistry and origin. Eclogae geol. Helv., 76, 551-580.

Strasser, A., Pittet, B., Hillgärtner, H. and Pasquier, J.-B. (1999) Depositional sequences in shallow carbonate-dominated sedimentary systems: concepts for a high-resolution analysis. Sed. Geol., 128, 201-221.

Strohmenger, C., Deville, Q. and Fookes, E. (1991) Kimmeridgian/Tithonian eustacy and its imprints on carbonate rocks from the Dinaric and the Jura carbonate platforms. Bull. Soc. géol. Fr., 162, 661-671.

Sun, S.Q. (1994) A reappraisal of dolomite abundance and occurrence in the Phanerozoic. J. Sed. Res., 64, 396-404.

Taylor, S.P. and Sellwood, B.W. (2002) The context of lowstand events in the Kimmeridgian (Late Jurassic) sequence stratigraphic evolution of the Wessex-Weald Basin, Southern England. Sed. Geol., 151, 89-106.

Taylor, S.P., Sellwood, B.W., Gallois, R.W. and Chambers, M.H. (2001) A sequence stratigraphy of the Kimmeridgian and Bolonian stages (Late Jurassic): Wessex-Weald Basin, southern England. J. Geol. Soc. London, 158, 179-192.

Termier, H., Termier, G. and Ramalho, M. (1985) Sur les Spongiofaunes de l'Oxfordien supérieur et du Kimméridgien du Portugal; description du Neuroporidé Periomipora elegantissima nov. C. R. Acad. Sci. Paris, 300, 975-980.

Thalmann, H.K. (1966) Zur Stratigraphie des oberen Malm im südlichen Berner und Solothurner Jura. Mitt. natf. Ges. Solothurn, 22, 4-25.

Thierry, J. (2000) Early Kimmeridgian. In: Atlas Peri-Tethys, Palaeogeographical Maps - Explanatory Notes (Ed. S.C. Coord), pp. 85-97. CCGM/CGMW, Paris.

Thierry, J. et al. (41 co-authors) (2000) Early Kimmeridgian. In: Atlas Peri-Tethys, Palaeogeographical Maps (Eds J. Dercourt, M. Gaetani et al.), map 10. CCGM/CGMW, Paris. 
Turnsek, D., Buser, S. and Ogorelec, B. (1981) An Upper Jurassic reef complex from Slovenia, Yugoslavia. In: European Fossil Reef Models (Ed. D.F. Toomey), SEPM. Spec. Publ., 30, 361-369.

Vail, P.R., Audemard, F., Bowman, S.A., Eisner, P.N. and Perez-Cruz, C. (1991) The stratigraphic signatures of tectonics, eustasy and sedimentology - an overview. In: $C y-$ cles and Events in Stratigraphy (Eds G. Einsele, W. Ricken and A. Seilacher), pp. 617-659. Springer-Verlag, Berlin.

Weissert, H. and Mohr, H. (1996) Late Jurassic climate and its impact on carbon cycling. Palaeogeogr. Palaeoclim. Palaeoecol., 122, 27-43.

Wernli, R. and Fookes, E. (1992) Troglotella incrustans n. gen., n. sp., un étrange et nouveau foraminifère calcicavicole du complexe récifal kimméridgien de Saint-Germain-de-Joux (Ain, France). Boll. Soc. Paleont. Ital., 31, 95-103.

Wignall, P.B. (1994) Black Shales. Oxford Monographs on Geology and Geophysics, 30, 127 pp.

Wright, V.P. (1994) Paleosols in shallow marine carbonate sequences. Earth-Sci. Rev., 35, 367-395.

Ziegler, P.A. (1988) Late Jurassic-Early Cretaceous Central Atlantic sea-floor spreading, closure of Neo-Tethys, and opening of Canada Basin. In: Evolution of the Artic-North Atlantic and the Western Tethys (Ed. P.A. Ziegler), AAPG Mem., 43, 63-82. 